\title{
СУТНІСТЬ І СТРУКТУРА ПОНЯТТЯ «ПРОФЕСІЙНА КОМПЕТЕНТНІСТЬ»
}

Шиба А.В. Суть і структура поняття «професійна компетентність».

У статті розглянуто сутність $i$ структуру професійної компетентності фахівия, подано авторське формулювання поняття «професійна компетентність».

Ключові слова: компетентність, професійна компетентність, структура професійної компетентності.

Шиба А.В. Суть и структура понятия «профессиональная компетентность».

В статье рассматривается суть и структура профессиональной компетентности специалиста. Предоставлено авторское определение понятия «профессиональная компетентность».

Ключевые слова: компетентность, профессиональная компетентность, структура профессиональной компетентности.

Shiba A. The nature and structure of the concept of "professional competence".

The paper deals with the nature of specialist's professional competence and its structure. The author also presents her definition of the notion "professional competence".

Key words: competence, professional competence, the structure of the professional competence.

Постановка проблеми. Необхідність реформування освіти, як за кордоном, так і в Україні, викликала появу нових концептуальних підходів i вимог до неї. Компетентнісний підхід, який був уперше запроваджений у сфері економіки та менеджменту, впевнено заявив про себе і в галузі освіті. Проте обговорення і дискусії, які постійно ведуться теоретиками і практиками в галузі педагогіки і психології, свідчать про неоднозначність у його розумінні й розв'язання значної кількості питань, що пов'язані з цим.

Аналіз останніх досліджень і публікацій. Термін «професійна компетентність» походить від латинських слів professio - що означає офіційно вказане заняття, професію та competentia - узгодженість, відповідність частин цілого, яке в свою чергу є похідним від слова competo збігатися, підходити, відповідати, узгоджуватись, бути здатним.

Російсько-англійська енциклопедія $Є$. Трифонова «Психофізіологія людини»[1] визначає професійну компетентність як якість, властивість або стан спеціаліста, що разом чи окремо забезпечує його фізичну, психічну й духовну відповідність необхідності, потребам, вимогам певної професії, спеціальності, спеціалізації, стандартам кваліфікації, службовій посаді, яку обіймає фахівець. Складовими професійної компетентності вважають мінімальний і достатній набір конструктів, що відповідають стандартам кваліфікації певної спеціальності й визначають професійну компетентність фахівця.

Аналіз праць вітчизняних i зарубіжних науковців С. Батишева, Т. Браже, І. Ісаєва, В. Кричевського, В. Лєдньова, А. Маркова, В. Маслова, В. Монахова, О. Новікова, О. Пометун, Дж. Равена, В. Сластьоніна, А. Хуторського та інших виявив, що нині в науці не запропоновано однозначного трактування сутності цього поняття i його складників. Західні науковці 
стверджують, що набуття й розвиток компетентності зумовлює інтенсифікацію інтелектуального та культурного розвитку, формування здатності орієнтуватися і пристосовуватись до умов життя, що швидко змінюються, а також до активізації життєвої позиції особистості. Особлива увага у структурі компетентності приділяється когнітивному і афективному складникам, мотивації, яка розглядається в аспекті цінностей, та цілевизначенню, досвіду у вирішенні професійних задач та інтуїції. Як підсумок досліджень російських науковців питання професійної компетентності можна навести слова В. Введенського: «У педагогічній науці поняття «професійна компетентність» розглядається як: сукупність знань та умінь, які визначають результативність праці; обсяг навичок виконання задачі; комбінація особистісних якостей i властивостей; комплекс знань та професійно значимих особистих якостей; вектор професіоналізації, єдність теоретичної і практичної готовності до праці; здатність здійснювати складні культуровідповідні види дій, тощо» [2, с. 51]. Така різноплановість у трактуванні даного поняття, на думку автора, зумовлена різноманітністю наукових підходів - особистісно-діяльнісного, системно-структурного, знаннєвого, культурологічного тощо. Не відзначаються одностайністю й думки вітчизняних дослідників, які зазначають, що професійна компетентність $є$ складним, інтегрованим й різноплановим поняттям.

Мета статті - на грунті аналізу й узгодження різних підходів запропонувати визначення та структуру досліджуваного поняття для його подальшого застосування в дослідженні питання формування професійної компетентності майбутніх перекладачів.

Виклад основного матеріалу. У зарубіжній науковій літературі термін «професійна компетентність» виник на початку 70-х років минулого століття і означав здатність особи виконувати роботу належним чином. Уперше в такому розумінні він з'явився у статті Крейга Ландберга «Розробка програми розвитку керівника» («Planning the Executive Development Program») у 1972 p.

Подальшого розгляду поняття набуло в працях Дейвіда МакКлелленда, який у своїй статті «Тестування компетентності, а не інтелекту» («Testing for Competence Rather Than for Intelligence) зазначає, що ані тести, ані шкільні оцінки не можуть значною мірою прогнозувати справжню компетентність у розв'язанні багатьох життєвих завдань. Він також виокремлює «традиційні компетентності», такі, як читання, письмо, уміння рахувати та деякі особистісні характеристики (навички спілкування, терпіння, постановку помірних цілей, саморозвиток, чим власне і прокладає шлях для появи поняття «ключові компетентності». Важливим для педагогічної науки $\epsilon$ висновок МакКлелленда про те, що процедура тестування компетентності має бути відкритою й зрозумілою як для викладача, так і для учня, що допомагає в подальшому розвивати іiі.

Намагаючись удосконалити визначення поняття «компетентність» та науково обгрунтувати процедуру оцінювання рівня іï сформованості. Джон Равен аналізує та узагальнює досвід багатьох зарубіжних дослідників. Він звертає увагу світової громадськості на недосконалість у розумінні й 
підходах до розвитку та оцінювання компетентності в сучасній системі освіти. Значну увагу у структурі компетентності Д. Равен приділяє мотивації. До інших складників компетентності він відносить когнітивні, афективні, конативні компоненти поведінки, а також звички й досвід.

Цікавою в аспекті нашого дослідження є праця Г'юберта Дрейфуса та Стюарта Дрейфуса, яку вони назвали «Від Сократа до експертних систем» [6]. Досліджуючи питання створення штучного інтелекту, вони аналізують феномен кваліфікованої поведінки на прикладі набуття дорослими нових умінь у процесі навчання, виокремлюючи при цьому декілька рівнів:

1. Новачок. Зазвичай процес навчання починається з того, що інструктор виокремлює у завданні незалежні від ситуації поняття, які початківець може розпізнати без попереднього досвіду виконання таких завдань. Потім йому даються правила для визначення дій, які з цими поняттями потрібно виконати. Це є подібним до того, як комп’ютер виконує програму.

2. Новачок, який вже досягнув певних успіхів. Під час того як новачок набуває досвіду, виконуючи завдання в реальних ситуаціях, він починає помічати, або інструктор вказує йому на важливі але доступні для його розуміння додаткові аспекти ситуації. Після розгляду достатньої кількості прикладів учень навчається розпізнавати ці додаткові аспекти.

3. Компетентний. Із набуттям досвіду кількість додаткових елементів, які здатний розпізнати учень стає переважаючою. У цій точці виконання завдання викликає знервованість і виснаження, оскільки розуміння того, що важливо в цій ситуації, а що ні, в учня відсутнє. Компетентний працівник шукає нові правила і процедури аргументації, які допомагають обрати план, вони не такі легкі, як ті, що подаються новачкам. На цій стадії працівник почувається відповідальним за невдачі. Оскільки компетентний працівник все більше і більш емоційно занурюється у виконання завдань, для нього стає все важче слідувати окремим правилам, які виконують новачки. I хоча може видатися, що таке занурення не сприяє виконанню правил i може гальмувати розвиток умінь i навичок, у дійсності картина абсолютно протилежна. Насправді можна побачити: якщо позиція прямого слідування окремим правилам новачками та новачками, що досягнули певних успіхів, змінюється на позицію занурення, людину очікує подальший розвиток, водночас опір прийняттю ризиків і відповідальності може призвести до застою, і врешті навіть до нудьги й регресу.

4. Досвідчений. Якщо в процесі набуття умінь i навичок завдання виконуються $з$ емоційним зануренням у діяльність, то як позитивний, так i негативний досвід будуть сприяти успішним діям і зменшувати кількість невдалих. Уявлення учня про уміння й навички як про низку правил i принципів поступово перетворюватиметься в розпізнавання ситуацій, які вимагають відповідних дій. Досвідченість приходить тоді, і тільки тоді, коли досвід набувається таким практичним способом, а інтуїтивна поведінка витісняє дії за правилами. Зацікавлений, досвідчений виконавець усвідомлює лише мету і головні аспекти ситуації, а не дії, які треба виконати, щоб 
досягнути цієї мети. Однак досвідчений виконавець після визначення мети і важливих рис ситуації все ж таки має вирішити, що робити. Щоб це вирішити, він повертається до незалежних правил.

5. Експерт. Досвідчений виконавець, занурений у світ своєї майстерної діяльності, бачить, що потрібно зробити, але має вирішувати, як це зробити. Експерт не лише бачить, що потрібно зробити завдяки значній кількості відпрацьованих ситуацій, але й бачить як досягнути мети. Здатність до більш тонкого і досконалого ситуаційного аналізу саме й відрізняє експерта від досвідченого виконавця. Експерт навчився розрізняти велику кількість ситуацій, які здаються однаковими досвідченому, проте одні ситуації вимагають одних дій, а інші - інших. Тобто, 3 достатнім досвідом у розв'язанні низки ситуацій, які розглядаються в межах однісї перспективи, але вимагають різних тактичних рішень, мозок експерта поступово розподіляє цей клас ситуацій на підкласи, кожен із яких вимагає подібних дій. Це викликає інтуїтивну і негайну реакцію, яка й притаманна експертам. Зазвичай експерт не прораховує, не слідує жодним правилам. Він просто вміє розпізнати тисячі особливих ситуацій.

Отже, автори доходять висновку, що новачки, досвідчені новачки та компетентні працівники виявляють «раціональність, що грунтується на розрахунках», а експерти - «внутрішню раціональність». Однак Г’юберт Дрейфус та Стюарт Дрейфус застерігають, що в сучасному, бюрократичному за своєю природою суспільстві, зростає загроза знищення рівня експерта через надмірне покладання на розрахунки, оскільки вони, на відміну від інтуїтивних, внутрішньо раціональних рішень, здаються очевидними i логічними для широкого загалу.

Значний внесок у дослідження проблеми професійної компетентності зробили також фахівці з ближнього зарубіжжя. Так, наприклад, російські дослідники В. Болотов та В. Сєріков, грунтуючись на особистісному підході, дійшли висновку, що компетентність існує в різних формах: рівня вмілості, способу особистісної самореалізації, певного підсумку саморозвитку індивіда чи форми виявлення його здібностей. Важливим у їх трактуванні компетентності $€$ висновок про те, що вона, будучи продуктом навчання, не прямо витікає 3 нього, а скоріше $є$ наслідком саморозвитку індивіда, самоорганізації та узагальненням діяльнісного та особистісного досвіду. Щодо професійної компетентності автори зазначають, що вона не тотожна проходженню курсу, а пов'язана 3 деякими додатковими передумовами розвитку спеціаліста, його власним творчим потенціалом та якістю освіти, яку він одержав.

I. Зимня, намагаючись поєднати культурологічний та особистіснодіяльнісний підходи, визначає професійну компетентність як актуальну особистісну якість, яка підлягає формуванню і основується на знаннях, інтелектуально й особистісно зумовлену соціально-професійну характеристику людини, іiі особистісну якість, яка полягає в адекватності розв'язання (стандартних та особливо нестандартних, таких, що вимагають творчості) 
задач усьому різноманіттю соціальних і професійних ситуацій і виявляється в діях, діяльності, поведінці, вчинках людини. До складу професійної компетентності І. Зимня відносить чотири блоки: базовий, особистісний, соціальний і професійний.

Базовий блок у цій концепції подано як такий, що забезпечує функціонування основних мисленнєвих операцій випускника вищого навчального закладу на рівні норми розвитку, а саме: аналізу, синтезу, зіставлення, систематизації, прийняття рішень, прогнозування, співвіднесення результату діяльності меті. Особистісний блок передбачає володіння випускником такими якостями, як відповідальність, організованість та цілеспрямованість. Соціальний блок забезпечує адекватність взаємодії людини 3 іншими людьми, групою, колективом. Відповідно до цього випускник має бути здатним організовувати своє життя згідно з соціально значимим уявленням про здоровий спосіб життя, керуватися правами і обов’язками громадянина, цінностями буття, культури, соціальної взаємодії, вибудовувати й реалізовувати перспективні лінії саморозвитку, інтегрувати знання в процесі їх набуття й використовувати їх у розв’язання соціальнопрофесійних задач, співпрацювати, керувати людьми й підкорятися, спілкуватися усно і письмово рідною й іноземною мовами, знаходити рішення в нестандартних ситуаціях, знаходити творчі розв'язання соціальних i професійних задач тощо. Професійний блок пов'язаний 3 адекватним виконанням професійної діяльності, відтак випускник повинен вміти розв’язати професійні задачі за своєю спеціальністю, призначенням [4].

Російський науковець А. Маркова до структури професійної компетентності відносить спеціальну, соціальну, особистісну та індивідуальну компетентність, де спеціальна компетентність співвідноситься 3 наявністю спеціальних знань та умінням використовувати їх на практиці, соціальна - 3 оволодінням способами спільної професійної діяльності, співробітництва та професійного спілкування, особистісна - 3 оволодінням способами самовираження та саморозвитку, планування професійної діяльності, а індивідуальна - 3 прийомами саморегуляції, готовності до професійного зростання, наявністю постійної професійної мотивації.

А. Хуторский у своїй доповіді [5] розмежовує поняття «компетенція» i «компетентність» i зазначає, що «компетенція» - включає сукупність взаємопов’язаних якостей особистості (знань, умінь, навичок, способів діяльності), що визначаються відпповідно до певного кола предметів і процесів, необхідних для якісної продуктивної діяльності стосовно них. Компетентність - володіння людиною відповідною компетенцією, що включає її особисте ставлення до неї і предмета діяльності.

Українські дослідники також зробили свій внесок у розгляд цього питання. Так, О. Онаць [6] визначає піi як «інтегральне утворення, що репрезентоване системою теоретичних знань, практичних умінь, соціально значущих i професійно важливих якостей особистості, сформованої мотиваційно-ціннісної сфери та набутого досвіду, діалектичний взаємозв’язок 
яких забезпечує результативність його професійної педагогічної діяльності». I. Полубоярина [7] доводить, що професійну компетентність слід розглядати як інтегративне утворення, в основі якого лежать професійні знання і вміння, особистісні якості та досвід, що обумовлює здатність майбутнього фахівця до ефективного виконання професійної діяльності. Використовуючи праці сучасних дидактів I. Чемерис пропонує таке формулювання: «Професійна компетентність - це система теоретичної і практичної готовності особистості до ефективної самореалізації у професії, що реалізується через парадигму професійно значущих знань, умінь, якостей, здібностей, схильностей та досвіду професійної діяльності» [8, с.9].

В. Федина визначає професійну компетентність як інтегральне системне утворення, що забезпечує якість професійної діяльності. Н. Лалак характеризує професійну компетентність як «складне особистісне утворення людини, що оптимально поєднує знання, уміння, навички, мотиви, ціннісні орієнтації, ставлення особистості; визначає здатність людини до самореалізації й самовизначення» [9, с.9]. У формулюванні Я. Сікори [10] професійна компетентність розглядається як система знань, умінь, особистісних якостей, формування та розвиток яких дозволить розв'язувати типові професійні задачі, а також проблеми, що виникають у реальних ситуаціях професійної діяльності, що передбачає здатність людини до професійного та особистісного зростання.

Висновки. Отже, нами детально розглянуто поняття «професійна компетентність» у працях дослідників, які представляють різні країни світу, галузі науки та застосовують різні підходи до трактування його сутності та компонентного складу. За допомогою таких методів як аналіз, синтез, порівняння та зіставлення ми дійшли висновку, що «професійна компетентність» - це широке, багатопланове, інтегральне поняття, яке означає міру оволодіння професією, виявляється в адекватності розв'язання виробничих завдань і передбачає професійно-пізнавальний, особистісний та соціальний блоки. До професійно-пізнавального блоку ми відносимо професійно-необхідні знання, уміння, навички, теоретичне та творче мислення. Особистісний блок складається із таких компонентів, як мотиваційний, вольовий та емоційний. Соціальний блок, на нашу думку, становить здатність особистості фахівця здійснювати ефективну взаємодію 3 іншими учасниками професійної діяльності.

Перспективи подалыших розвідок убачаємо у визначенні сутності поняття «професійна компетентність перекладача» й особливостей його компонентного складу.

\section{Література}

1. Трифонов Е. В. Психофизиология человека [Электронный ресурс]: Русскоангло-русская энциклопедия. $\quad$ - $[14$ изд., 2011]. $\quad$ - Режим доступу: http:/tryphonov6/terms6/prcom.htm

2. Введенский В.Н. Моделирование профессиональной компетентности педагога / В. Н Введенский // Педагогика. - 2003. - №10. - С.51-55. 
3. Dreyfus H., Dreyfus S. From Socrates to Expert Systems: The Limits and Dangers of Calculative Rationality [Електроннийресурс] / Dreyfus Hubert L., Dreyfus Stuart Е. Режимдоступу: http://socrates.berkeley.edu/ hdreyfus/html/paper_socrates.html

4. Зимняя И.А. Общая культура и социально-профессиональная компетентность человека: [електронний ресурс] / Ирина Алексеевна Зимняя. - Режим доступу: // http://www.eidos.ru/journal/2006/0504.htm

5. Хуторской А.В. Ключевые компетенции и образовательные стандарты. [Електронний ресурс] / Хуторской Андрей Викторович. - Режим доступу: http://www.eidos.ru/journal/2002/0423.htm

6. Онаць О. М. Управління розвитком професійної компетентності молодого вчителя загальноосвітнього навчального закладу: автореф. дис. на здобуття наук. ступ. канд. пед. наук: 13.00.01 / Онаць Олена Миколаївна; Інститут педагогіки АПН України. К., 2006. - 21с.

7. Полубоярина I. I. Формування професійної компетентності майбутніх учителів музики в педагогічному коледжі : автореф. дис. на здобуття наук. ступ. канд. пед. наук: 13.00 .04 / Полубоярина Ірина Іванівна; Житомирський держ. ун-т ім. Івана Франка. Житомир, 2008. - 20 с.

8. Чемерис I. М. Формування професійної компетентності майбутніх журналістів засобами іншомовних періодичних видань: автореф. дис. на здобуття наук. ступен. канд. пед. наук: 13.00.04 / Чемерис Інна Михайлівна ; Інститут вищої освіти АПН України. - К., 2008. - 20c.

9. Лалак Н.В. Формування професійної компетентності майбутнього вчителя в процесі навчання історії: автореф. дис. на здобуття наук. ступ. канд. пед. наук: 13.00.02 / Лалак Наталія Володимирівна; Ін-т педагогіки АПН України. - К., 2009. - 20 с.

10. СікораЯ.Б Формування професійної компетентності майбутнього вчителя інформатики засобами моделювання : автореф. дис. на здобуття наук. ступ. канд. пед. наук: 13.00.04 / Ярослава Богданівна Сікора; Житомир. держ. ун-т ім. І.Франка. Житомир, 2010. - 20 с.

Стаття надійшла до редакції 24.05.2012 р.

УДК 371.15

О. Л. Титунь, викладач, Прикарпатський національний університет ім. В. Стефаника

\section{НАУКОВО-ДОСЛІДНА РОБОТА ЯК ЗАСІБ ПІДВИЩЕННЯ ГОТОВНОСТІ МАЙБУТНІХ УЧИТЕЛІВ ДО ОРГАНІЗАЦЇ̈ ПОЗАКЛАСНОЇ ВИХОВНОЇ РОБОТИ 3 МОЛОДШИМИ ШКОЛЯРАМИ}

Титунь О.Л. Науково-дослідна робота як засіб підвищення готовності майбутніх учителів до організаиії позакласної виховної роботи з молодшими школярами.

У статті розглянуто особливості науково-дослідної роботи з майбутніми вчителями. Така робота визначається як один з основних засобів підвищення готовності студентів до подальшої організачії позакласної виховної роботи з молодшими школярами.

Ключові слова: науково-дослідна робота, позакласна виховна робота, молодші школярі.

Титунь О.Л. Научно-исследовательская работа как способ повышения готовности будущих учителей к организации внеклассной воспитательной работы с младщими школьниками.

В статье рассматриваются особенности научно-исследовательской работы с будущими учителями. Научно-исследовательскую работу определяют как основной способ улучшения готовности к организачии внеклассной воспитательной работы со школьниками младших классов. 